The University of Maine

\title{
DigitalCommons@UMaine
}

Earth Science Faculty Scholarship

Earth Sciences

$3-1-2002$

\section{Investigating Peatland Stratigraphy and Hydrogeology Using Integrated Electrical Geophysics}

Lee D. Slater

Andrew S. Reeve

University of Maine - Main, asreeve@maine.edu

Follow this and additional works at: https://digitalcommons.library.umaine.edu/ers_facpub Part of the Earth Sciences Commons

\section{Repository Citation}

Slater, Lee D. and Reeve, Andrew S., "Investigating Peatland Stratigraphy and Hydrogeology Using Integrated Electrical Geophysics" (2002). Earth Science Faculty Scholarship. 54.

https://digitalcommons.library.umaine.edu/ers_facpub/54 


\title{
Case History
}

\section{Investigating peatland stratigraphy and hydrogeology using integrated electrical geophysics}

\author{
Lee D. Slater* and Andrew Reeve
}

\begin{abstract}
Hydrology has been suggested as the mechanism controlling vegetation and related surficial pore-water chemistry in large peatlands. Peatland hydrology influences the carbon dynamics within these large carbon reservoirs and will influence their response to global warming. A geophysical survey was completed in Caribou Bog, a large peatland in Maine, to evaluate peatland stratigraphy and hydrology. Geophysical measurements were integrated with direct measurements of peat stratigraphy from probing, fluid chemistry, and vegetation patterns in the peatland. Consistent with previous field studies, ground-penetrating radar (GPR) was an excellent method for delineating peatland stratigraphy. Prominent reflectors from the peat-lake sediment and lake sediment-mineral soil contacts were precisely recorded up to $8 \mathrm{~m}$ deep. Two-dimensional resistivity and induced polarization imaging were used to investigate stratigraphy beneath the mineral soil, beyond the
\end{abstract}

range of GPR. We observe that the peat is chargeable, and that IP imaging is an alternative method for defining peat thickness. The chargeability of peat is attributed to the high surface-charge density on partially decomposed organic matter. The electrical conductivity imaging resolved glaciomarine sediment thickness (a confining layer) and its variability across the basin. Comparison of the bulk conductivity images with peatland vegetation revealed a correlation between confining layer thickness and dominant vegetation type, suggesting that stratigraphy exerts a control on hydrogeology and vegetation distribution within this peatland. Terrain conductivity measured with a Geonics EM31 meter correlated with confining glaciomarine sediment thickness and was an effective method for estimating variability in glaciomarine sediment thickness over approximately $18 \mathrm{~km}^{2}$. Our understanding of the hydrogeology, stratigraphy, and controls on vegetation growth in this peatland was much enhanced from the geophysical study.

\section{INTRODUCTION}

The striking vegetation gradients and patterning present in peatlands have led many researchers to speculate on the processes that control peatland development (Mitsch and Gosselink, 1993). Recent conceptual peatland models invoke hydrogeologic processes as a controlling factor in the development of vegetation patterns (Siegel, 1983; Siegel and Glaser, 1987; McNamera et al., 1992; Reeve et al., 2000). These processes regulate the supply of solutes to the peat surface, controlling the surface-water chemistry and the supply of nutrients to plants (Malmer, 1986; Glaser, 1987; Glaser et al., 1997). In particular, hydrology shapes the development of two peat landforms: bogs and fens. Bogs are topographic domes characterized by nutrient-poor and low-pH surface water that support a low-diversity plant community dominated by Sphagnum moss and ericaceous shrubs (Glaser et al., 1981; Gorham et al., 1985; Shotyk, 1988). In contrast, the flat or concave fen surface holds surface waters with higher $\mathrm{pH}$ and nutrients, and supports a greater diversity of plants with more abundant sedges and less abundant Sphagnum mosses and ericaceous shrubs. Bogs are thought to receive nutrients solely from precipitation, whereas fens receive nutrients carried by groundwater and surface-water influx.

Over the past twenty years, peatlands have received increased attention because they are linked to the global carbon cycle and impact greenhouse gas concentrations $\left(\mathrm{CO}_{2}, \mathrm{CH}_{4}\right)$

Manuscript received by the Editor October 23, 2000; revised manuscript received May 15, 2001.

*Univ. of Missouri-Kansas City, Department of Geosciences, 5100 Rockhill Road, Kansas City, Missouri 64110. E-mail: SlaterL@umkc.edu.

UUniversity of Maine, Department of Geological Sciences, 5790 Bryand Global Sciences Center, Orono, Maine 04469. E-mail: asreeve@maine.edu. (C) 2002 Society of Exploration Geophysicists. All rights reserved. 
in the atmosphere (Gorham, 1991; Glooschenko et al., 1994). Hydrogeology will also impact the carbon cycling within a peatland through the transport of dissolved organic carbon and other solutes that affect the production of carbon gases in the peatland (Siegel et al., 1995; Waddington and Roulet, 1997). Because the hydrogeology of a peatland is linked to the structure and permeability of subsurface materials, an understanding of the stratigraphy below the peatland will aid in developing an understanding of the hydrogeology of a peatland.

Geophysical methods have the potential to assist understanding of peatland stratigraphy and hydrogeology. Only ground-penetrating radar (GPR) has been extensively used in this respect. Depending on the electrical conductivity of the peat, GPR can penetrate up to $10 \mathrm{~m}$ in peatlands, with a resolution of 10-15 cm (Lowe, 1985; Theimer et al., 1994). The method is effective as moisture content changes occur at important interfaces, causing measurable GPR reflections. These moisture content changes are related to changes in sediment type, bulk density, and organic matter content (Warner et al., 1990). Numerous studies illustrate the potential of the method for identifying the base of a peatland (Lowe, 1985; Meyer, 1989; Warner et al., 1990; Pelletier et al., 1991; Poole et al., 1997). Peat can contain up to about $95 \%$ water, with water content varying with degree of decomposition and the plant types that make up the peat (Hobbs, 1986). Moisture content typically drops to $30-40 \%$ in the mineral soil, resulting in large-amplitude reflections at the peat-mineral soil contact (Hanninen and Hanninen, 1991; Theimer et al., 1994). Significant reflectors within peat have also been identified and associated with local changes in moisture content due to density changes (Warner et al., 1990), ash layers, wood layers, and zones of open water (pipes) (Theimer et al., 1994). Variation in the degree of peat humification (degree of decomposition) may also cause a GPR response (Lowe, 1985; Warner et al., 1990). Reflections from boundaries between different types of peat and the interface between peat and organic-rich lake sediment are also identifiable (Hanninen, 1992). As the dielectric constant of peat is well known [50-70, depending on peat type (Theimer et al., 1994)], reliable estimates of the depth to reflectors within and at the base of peat are obtainable. Peat velocity is easily measured from the strong reflector at the peat-mineral soil contact, using the common-midpoint (CMP) method. Hanninen (1992) and Jol and Smith (1995) suggest that, where peat sediment contact consists of lake sediment or clay, peat probes have limited accuracy, and GPR provides a more accurate, lower cost measure of peat thickness.

As relative permittivity of peat depends on degree of decomposition, GPR facilitates examination of the development history of peatlands. Warner et al. (1990) interpret GPR data in terms of volumes of economically extractable peat deposits. Jol and Smith (1995) use GPR to guide emplacement of oilfield pipelines through peatlands in Alberta. However, effectiveness of the GPR method in peatland studies is limited by certain factors. First, where bulk electrical conductivity of peat is high, electromagnetic (EM) wave propagation is attenuated, and depth of penetration in peat reduced (Nobes et al., 1989; Theimer et al., 1994; Poole et al., 1997). Second, where the mineral soil is clay rich, GPR is limited to investigating electrical properties above the mineral contact because clay rapidly attenuates the EM wave. The composition and variability of the mineral soil exerts a significant control on the hydrogeology and water chemistry of a peatland (Bridgham et al., 1996).
Consequently, integrated geophysical studies that provide information on physical properties beneath the mineral contact may improve understanding of the stratigraphy, hydrogeology, and hydrochemistry of peatlands.

Direct current (dc) resistivity and induced polarization (IP) methods may assist peatland studies, particularly for examining the relation between mineral soil stratigraphy and properties of peat. Unlike GPR, these methods are not typically limited to studies above the mineral soil. Bulk conductivity $\left(\sigma_{b}\right)$ measured in the dc resistivity method depends upon fluid conductivity $\left(\sigma_{w}\right)$, moisture content $(\theta)$, and surface conduction $\left(\sigma_{s}\right)$. As peat is predominantly water, $\sigma_{b}$ is particularly dependent on $\sigma_{w}$. The shallow pore fluids in boreal peatlands are typically relatively dilute because rainfall is the primary input of water and the organic peat usually does not contain a substantial amount of soluble material. The electrical conductivity of peat pore water usually increases with depth because the mineral soil underlying the peat is a source of inorganic solutes. As highly decomposed plant material within peat has a high surface charge, surface conduction is probably also significant in controlling bulk conductivity. These factors suggest that a significant contrast in electrical conductivity between peat and the underlying mineral soil is likely. Examples of the application of resistivity methods in peatland studies are limited. Meyer (1989) demonstrated the use of resistivity soundings to map variation in peat thickness in a basin where peat was conductive relative to the underlying mineral soil. Peat and mud layers were interpreted from 1-D resistivity inversions.

The IP method measures the magnitude of polarization of a material or, put simply, its ability to temporarily store charge. The IP effect manifests itself as a residual voltage following termination of an applied current (time-domain measurement) or as a frequency-dependent resistivity (frequency-domain measurement). The most common measure of IP is the timedomain chargeability $(M)$, whereby residual voltage is measured over some time window defined after termination of an applied current. In nonmetallic mineral soil, polarization results from diffusion-controlled polarization processes at the interface between the grain surfaces and the pore solution. The IP response thus depends on surface chemistry, which is controlled by charge density, surface area, and fluid chemistry. The large surface area and cation exchange capacity (CEC) associated with clay minerals enhances the magnitude of polarization in disseminated-clay sediments and rocks (Vinegar and Waxman, 1984). A small polarization is often measured for clay-free unconsolidated material (e.g., Vinegar and Waxman, 1984; Vanhala, 1997). The application of IP to the study of peatlands has never, to our knowledge, been reported and typical values of $M$ in peat are not documented. The high surface charge density associated with poorly decomposed organic material results in a high CEC (Hobbs, 1986). The CEC of peat is related to the plant type that forms the peat (bog peat has a higher CEC than fen peat) and to the degree of decomposition (CEC decreases with increasing decomposition) (Hobbs, 1986). As charge density is a major control on IP response, we expect the IP response of peat to be significantly different from the mineral soil.

EM terrain (or apparent) conductivity measurements are useful for rapid mapping of lateral variations in bulk electrical conductivity and are routinely used in site characterization studies of the near surface. The most commonly employed instrument, the Geonics EM31, measures bulk apparent 
conductivity of the near-surface material to a depth dependent on site conditions. Wende and Kirsch (1993) report application of an EM31 to studies of a peat bog in Germany. Terrain conductivity was proportional to peat thickness, but was also sensitive to mineral inclusions in the bog. Nobes et al. (1989) used an EM31 to determine bulk conductivity of peat in Mer Blue Bog, Ontario. Ayotte et al. (1999) observed that terrain conductivity in a New Hampshire wetland underlain by sand was primarily responsive to peat thickness and thickness of the water column.

In this paper, we report results of a field study to investigate the utility of electrical methods (resistivity imaging, IP imaging, GPR, and terrain conductivity mapping) for understanding the stratigraphy and hydrogeologic setting of a large peatland. Geophysical data are compared with direct sampling of peat thickness, peat composition, fluid chemistry, and vegetation patterns. Our primary objective was to demonstrate the value of an integrated geophysical approach to peatland studies. We highlight the important information obtained from the four electrical methods, and show the value of resistivity and IP for determining characteristics of the mineral soil not re- solvable from GPR. It was not our intention to determine the controls on the electrical properties of peat; further laboratory research is required to do this. Instead, we show how field electrical geophysics provides valuable insights into the stratigraphic and hydrogeological controls on a large peatland.

\section{SITE LOCATION, STRATIGRAPHY, HYDROGEOLOGY, AND VEGETATION}

Caribou Bog is a large (about 2200 ha) multiple-unit peatland extending $17 \mathrm{~km}$ south to north, from Bangor to Hudson, Maine (Figure 1). The peatland wraps around the northern, eastern, and southern sides of 12-km-long Pushaw Lake. Peat thickness reaches $13 \mathrm{~m}$, with as much as $5 \mathrm{~m}$ of underlying organic-rich lake sediment. The underlying mineral basement is a glaciomarine silt-clay, the Presumpscot Formation. Based on available regional geologic data, we suspect that a sand and gravel unit underlies the glaciomarine sediment. Sand was found beneath the glaciomarine sediment in deep cores obtained from the central unit of Caribou Bog, and sand/gravel is frequently encountered beneath glaciomarine sediment at many locations in Maine.

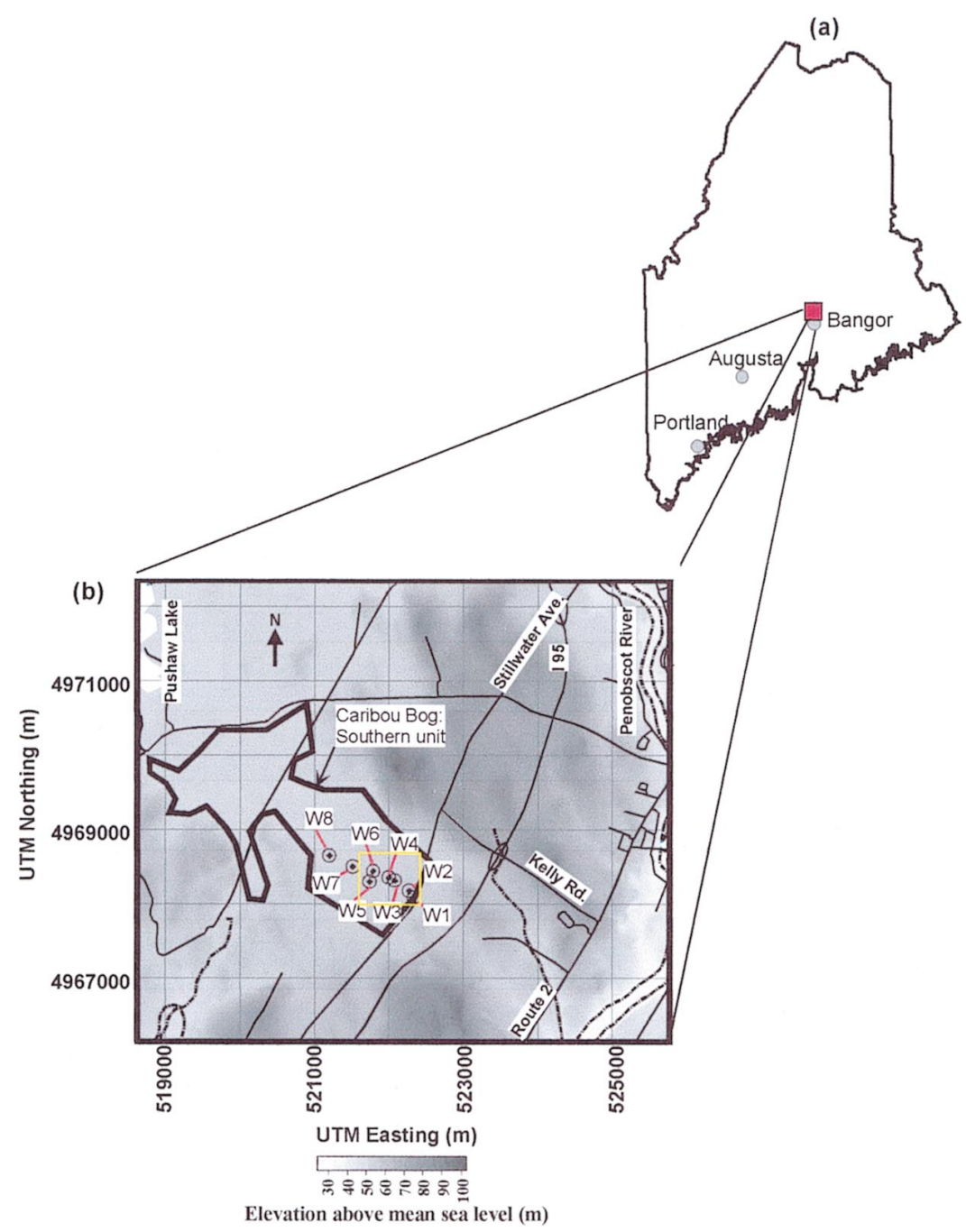

FIG. 1. (a) Location of Caribou Bog in Maine. (b) Position of monitoring wells and geophysical survey area in the southern unit of Caribou Bog, southeast of Pushaw Lake. Rectangle encompassing wells W1-W6 is extent of geophysical survey area shown in Figure 2. 
Caribou Bog's southernmost complex was the focus of this study. Nine monitoring well clusters are installed across the southern complex. Hydraulic head measurements at these wells indicate that groundwater generally flows to the northwest, with a slight water table mound present near wells W3 and W4. The hydraulic gradient between wells W1 and W3 is very low, but increases to about 0.0014 between wells W3 and W8. Vertical groundwater flow changes seasonally: groundwater flows upward from the mineral soil in the spring and downward in the summer. Present vegetation of the south complex consists of mixed wooded fen around well W1, forested bog (Picea mariana wells at W8; wooded shrub-heath at wells W2, W5, and W7; and shrub-heath at wells W3, W4, and W6). The location of geophysical profiling lines within the study area is shown in Figure 2. Line locations were determined by the position of existing monitoring wells and logistical restrictions caused by vegetation and accessibility. Line 0 was established as the reference profile along the long axis of the basin. Six transects were established at monitoring well locations or at the approximate midpoints between them.

\section{DIRECT SAMPLING}

Samples of peat and mineral soil were obtained at four locations (Figure 2) with a 1-m-long Russian peat corer. The major units identified in the peat are summarized in Figure 3.
Loosely compacted peat forms the major unit within the basin, reaching $4.6 \mathrm{~m}$ thick at $\mathrm{C} 2$. It is underlain by organic-rich lake sediment, up to $1.5 \mathrm{~m}$ thick at $\mathrm{C} 1$. A distinct silt band separates the peat and lake sediment at $\mathrm{C} 1, \mathrm{C} 2$, and $\mathrm{C} 3$. This is an important stratigraphic contact because it reflects a shift from deposition of detrital organics in a basin to in-situ growth of plants that later became peat. The underlying glaciomarine silt-clay is identified in each core but was impenetrable using the hand corer. Penetration tests were also performed along an $80-\mathrm{m}$ section of line 0 to determine small-scale variability in peat thickness. A pointed steel rod was pushed into the peat until refusal, marking the top of the glaciomarine sediment.

Fluid conductivity $\left(\sigma_{w}\right)$ in wells W1-W6 was measured at a depth of about $1 \mathrm{~m}$, at one or two intermediate depths, and at the peat-mineral soil interface using drive points. Additional measurements in the upper $1.5 \mathrm{~m}$ were made at points along line 0 and the $\mathrm{W} 6$ traverse. Conductivity within the peat ranges from 40 to $77 \mu \mathrm{S} / \mathrm{cm}$. Such low $\sigma_{w}$ values are indicative of surficial waters in northern raised peatlands that contain peat with little soluble material and are hydrologically isolated from external solute-rich sources of water (Siegel and Glaser, 1987; Shotyk, 1988). Within the upper $1.5 \mathrm{~m}, \sigma_{w}$ decreases with depth, presumably due to evaporation at the surface. At wells W4W6, $\sigma_{w}$ within the lake sediment is similar to $\sigma_{w}$ within the peat. However, $\sigma_{w}$ at well 3 increases from $50-70 \mu \mathrm{S} / \mathrm{cm}$ in the

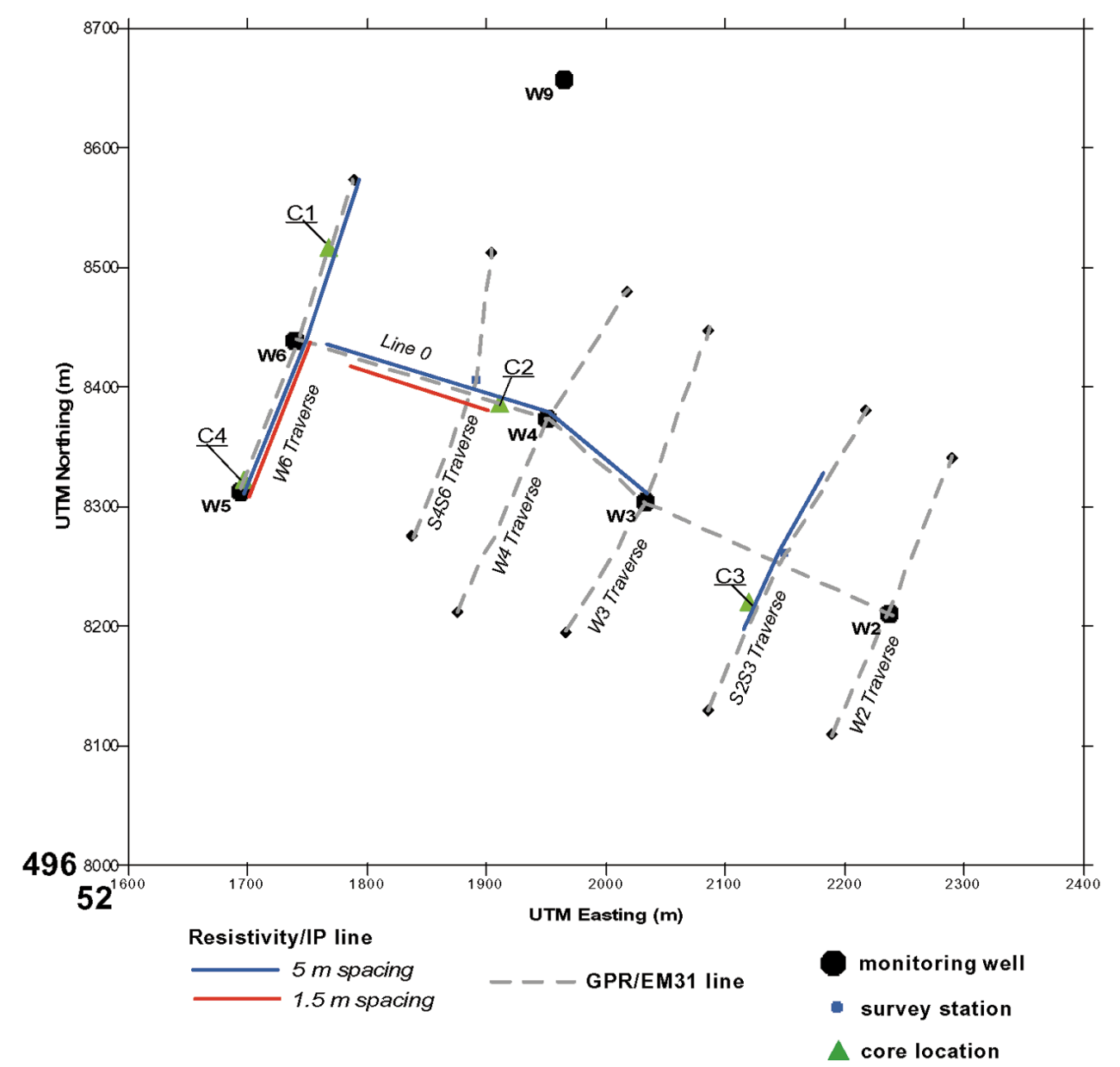

FIG. 2. Location of geophysical survey lines. Peat core and monitoring well positions are also shown. 
peat to $150 \mu \mathrm{S} / \mathrm{cm}$ in the lake sediment, indicative of solute exchange from the mineral basement.

\section{GPR}

GPR surveys using 100-MHz and 200-MHz antennas were performed along lines shown in Figure 2. The reduced depth of investigation obtained with the $200-\mathrm{MHz}$ antenna prevented detection of the peat-lake sediment and the lake sedimentglaciomarine sediment interface identified in the peat cores. Only $100-\mathrm{Mhz}$ data, in which these interfaces are recorded, are presented here. The relative dielectric constant $\left(\varepsilon_{r}\right)$ of peat is known from laboratory and field measurements to range from 51.4 to 70.4 , depending on the measurement method and specific peatland (Theimer et al., 1994). Using traveltime measurements to reflectors observed in peat cores, we calculated an average $\varepsilon_{r}$ of 61 for the peat in Caribou Bog. CMP soundings applied to the reflector at the base of the peat gave a comparable value. The optimal vertical resolution $\left(r e s_{v}\right)$ of a radar pulse is one-quarter of the wavelength $(\lambda)$ (Reynolds, 1997). Examination of the time trace obtained in the field revealed that the central frequency of our instrument in this environment was $91 \mathrm{MHz}$. Although the nominal frequency specified by the manufacturer was $100 \mathrm{MHz}$, high water content media tends to load the antenna and pull down the central frequency. For a $91-\mathrm{MHz}$ center frequency and $\varepsilon_{r}=61$,

$$
\operatorname{res}_{v}=\frac{\lambda}{4}=\frac{75}{f \times \sqrt{\varepsilon_{r}}}=0.11 \mathrm{~m},
$$

with $\lambda$ in meters (Theimer et al., 1994). The velocity ( $v$ ) of an electromagnetic wave is given by

$$
v=\frac{c}{\sqrt{\varepsilon_{r}}}
$$

where $c$ is velocity of a radar pulse in a vacuum $(0.3 \mathrm{~m} / \mathrm{ns})$. In our peatland, therefore, $v$ is $0.0385 \mathrm{~m} / \mathrm{ns}$. GPR measurements were made using a RAMAC system. The sampling time window was $490 \mathrm{~ns}$, providing a maximum investigation depth of $9.4 \mathrm{~m}$, assuming constant $\varepsilon_{r}$ with depth. Maximum lakeinorganic glaciomarine sediment interface depth observed in the cores was $6.1 \mathrm{~m}$; thus, the selected time window was considered sufficient to map this interface across the survey area. The processing steps were limited to application of a dc offset, a time-varying gain, and conversion to an equivalent depth of investigation assuming $\varepsilon_{r}=61$.

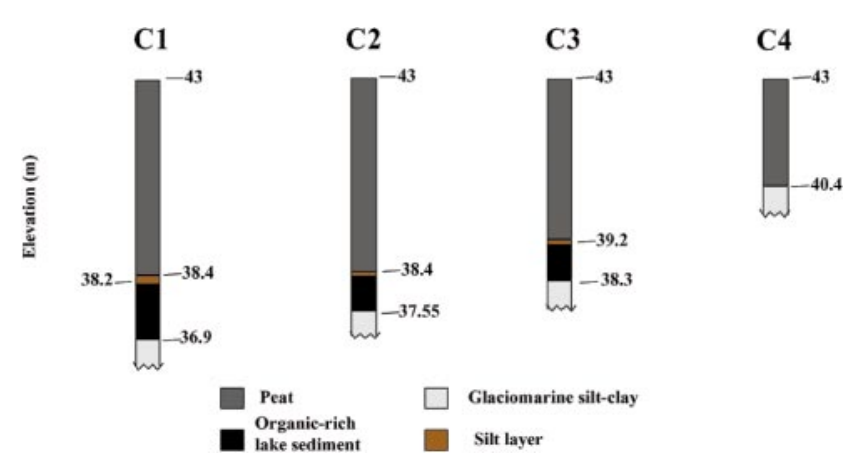

FIG. 3. Summary of peat cores obtained at locations C1-C4 shown in Figure 2 (absolute values of elevation are only ap-
proximate as a flat peat surface between cores is assumed).
GPR profiles along line 0 and the W6 traverse correlate with penetration tests (described above) and peat core data (Figure 4). We observe strong reflectors at the lakeglaciomarine sediment interface and at the peat-lake sediment interface. No reflectors were observed below the lakeglaciomarine sediment interface. Consequently, the radar records are truncated at $t=364 \mathrm{~ns}$ (equivalent depth $=7 \mathrm{~m}$ ) for presentation purposes. GPR reflections in peat primarily occur where water content changes. As the water table is only 30 $40 \mathrm{~cm}$ beneath the surface, it is not evident on the radar record. The strong reflector at the base of the lake sediment presumably results from a change in water content at this boundary. Volumetric water content in the glaciomarine sediment is probably $30-40 \%$, compared to $80-90 \%$ in the peat. Reflections from this contact are identified up to $8 \mathrm{~m}$ deep and correlate with the point of refusal in the penetration tests. The weaker reflection from the peat-lake sediment boundary may also be caused by a moisture content change, as the peat likely has a higher water content than the underlying lake sediment. However, it could also result from an increase in mineral content in the lake sediment. Lake sediment typically loses about 50\% of its mass when burned, whereas peat loses $95-100 \%$ when burned (loss on ignition tests) (Gajewski, 1987).

The texture of a GPR record is often indicative of changes in physical properties of sediments (Beres and Haeni, 1991). In our study, textural differences between peat and lake sediment are observed. The peat comprises numerous reflectors and diffractions, none of which appear laterally extensive. These internal features are partly attributed to woody layers within the peat, as observed in four peat cores. Ash layers and local changes in moisture content may also contribute. In contrast, the lake sediment is characterized by a lack of prominent reflectors or diffractions, most obvious in Figure $4 \mathrm{~b}$. The grainy nature of the lake sediment suggests more homogeneous sediment, as observed in the peat cores.

The GPR profiles record the variation in thickness of peat and lake sediment within the basin. Along the W5 traverse, the lake sediment thickness exceeds $3 \mathrm{~m}$ at $180 \mathrm{~m}$ but thins out and becomes absent towards well W5, approaching the edge of the peat basin. The center of the peat basin is well defined. Along line 0 (long axis of the basin) the lake-glaciomarine sediment contact is irregular, and the thickness of lake sediment varies considerably. Additional north-west to south-east GPR traverses further define the stratigraphy of the basin and crosssectional variability. Traverses at wells W3 and W2 are shown as examples in Figure 5, with sediment type interpreted from the GPR response. Vegetation growth on the W3 traverse prevented measurements south of $150 \mathrm{~m}$. The $\mathrm{W} 2$ traverse reveals an absence of lake sediment in the southeast corner of the basin.

\section{RESISTIVITY AND IP}

Measurements were made using a SYSCAL R1 resistivityIP receiver interfaced with an automated data acquisition unit. A dipole-dipole array configuration, with a maximum dipole separation $(n)$ of 6 , was employed. A 5-m electrode spacing was used to investigate the electrical structure of the peat basin and the underlying mineral sediments. A $1.5-\mathrm{m}$ array was used to better resolve the near-surface electrical structure of the peat and lake sediment. The location of resistivity-IP lines is shown in Figure 2. Resistivity and IP data were inverted using 
a smoothness-constrained, least-squares algorithm developed by MacInnes and Zonge (1996).

The spatial resolution of such inversions is not defined analytically, because it is an unknown function of many factors including measurement error, electrode geometry, number of independent measurements, and the resistivity distribution (Daily and Ramirez, 1995). This said, the spacing between electrodes exerts the fundamental control on resolution. Reducing the electrode spacing improves resolution but limits the volume that can be imaged. The theoretical optimal resolution is the size of an element in the finite-element mesh used in the forward modeling. Element size increases logarithmically with depth to account for the decrease in resolution that is unavoidable with increasing distance from the current source. The inherent nonuniqueness (equivalence problem) in 2-D resistivity/IP inversion, particularly at the base and edges of images, must also be factored into interpretations.

Conductivity and IP inversion results along line 0 using a 5-m electrode spacing are plotted in Figure 6. The peat-lake sediment and lake-glaciomarine sediment interfaces, as determined from GPR, are superimposed. Inversions along the W6 traverse are plotted in Figure 7. The conductivity inversion contains a uniform upper resistive layer, underlain by a conductive unit of varying thickness, underlain by a resistive third layer. The GPR control data show that conductivity is not an accurate indicator of peat thickness. The base of the conductive layer is considered the base of the glaciomarine sediment. In contrast, the top of the conductive layer appears to occur within the peat. The inversion for the $1.5-\mathrm{m}$ electrode spacing indicates a gradually increasing conductivity with depth in the peat (Figure 8). This may reflect the smearing of sharp interfaces by 2-D smoothness-constrained resistivity inversions, the model discretization and contouring employed, or nonuniqueness in the inversion result, or it may truly indicate changes in the electrical properties of the peat with depth. Fluid conductivity profiles at wells W4 and W6 suggest that it is not a function of fluid chemistry. This conductivity increase may reflect a change in the physical properties of the peat with depth as the transition from peat to lake sediment is approached. However, further detailed study of electrical conductivity profiles in the peat is required to validate this. We, therefore, consider the conductive unit resolved in the electrical imaging as an integrated response to the glaciomarine sediment, lake sediment, and possibly the lower portion of the peat.

(a)
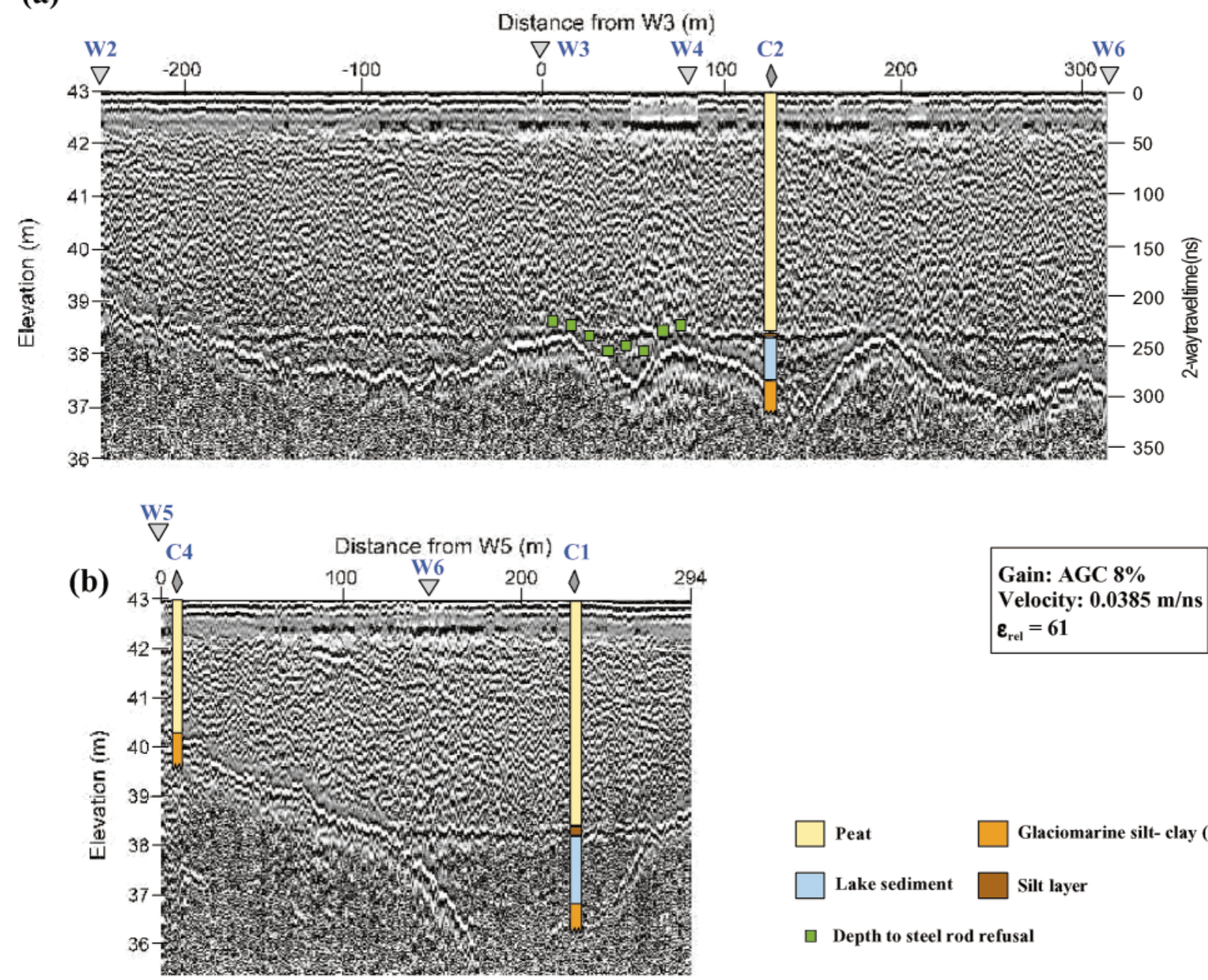

Gain: AGC 8\%

Velocity: $0.0385 \mathrm{~m} / \mathrm{ns}$ $\varepsilon_{\text {rel }}=61$

FIG. 4. Radar images correlated with peat cores and depth to refusal from penetration tests: (a) line 0, (b) W6 traverse. Refer to Figure 2 for survey line locations. 
The IP inversions resolve the peat as chargeable, relative to the underlying lake sediment and glaciomarine sediment. The chargeability $(M)$ appears to be an indicator of the peat thickness. This is most apparent in the W6 traverse, where an increase in thickness of the lake sediment between 150 and $250 \mathrm{~m}$ is not accompanied by an increase in thickness of the upper chargeable layer. This supports our premise that the lake sediment is electrically similar to the glaciomarine sediment and physically different from the overlying peat. The continuous lower resistive layer observed in the conductivity inversions is not evident in the IP inversions. Chargeability beneath $35-\mathrm{m}$ elevation is small, although it varies on both lines. As previously discussed, we suspect that a sand and gravel unit underlies the glaciomarine sediment. Laboratory measurements indicate that the chargeability of sand/gravel with minimal clay content is low (Vanhala et al., 1992). The variation in chargeability be- low $35 \mathrm{~m}$ elevation on both lines may possibly reflect changes in the lithology (likely clay content or grain size distribution) of this lower layer. However, it may simply reflect uncertainty in the inversion result because at depth the sensitivity is poor, discretization is coarse, and the equivalence problem is enhanced.

Slater and Lesmes (2002) emphasize that the dependence of $M$ on bulk conduction can complicate IP interpretation. A useful parameter is the normalized chargeability $\left(M_{N}\right)$, defined as the ratio of chargeability to resistivity. Whereas $M$ is a measure of polarization strength relative to bulk conduction, $M_{N}$ is a direct measure of polarization strength. The normalized chargeability is a better lithologic discriminator than chargeability because it is less influenced by fluid conductivity (Slater and Lesmes, 2002). Figure 9 shows the $M_{N}$ result for the 5 -m electrode spacing on the W6 traverse calculated from the

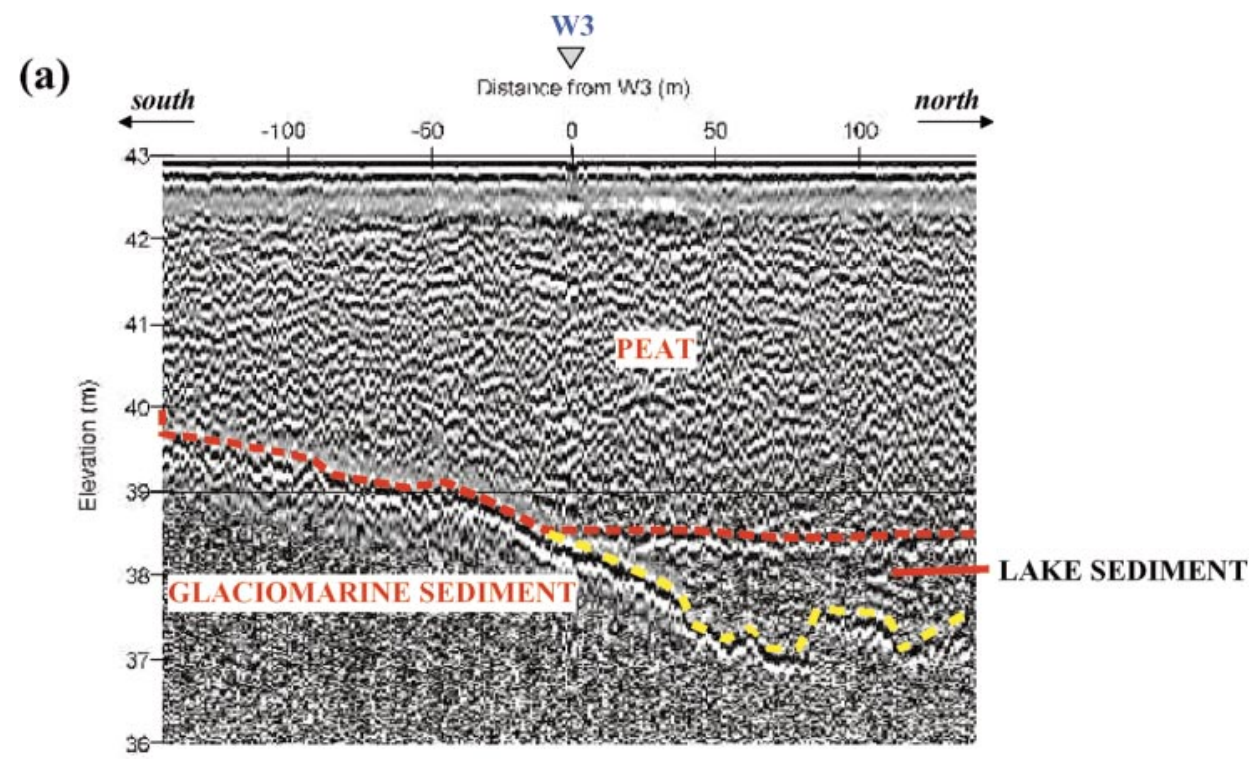

(b)

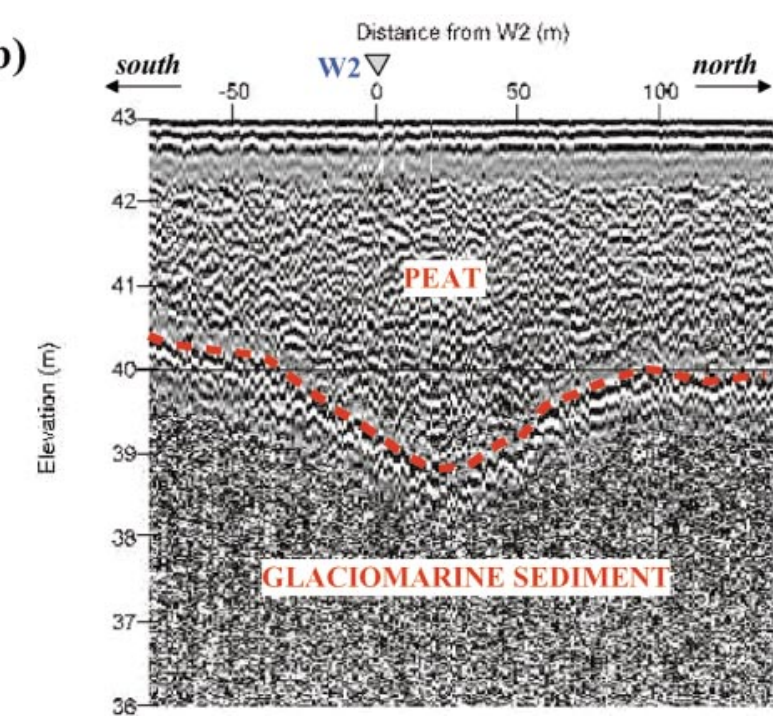

Gain: AGC 8\%

Velocity: $0.0385 \mathrm{~m} / \mathrm{ns}$

$\varepsilon_{\text {rel }}=61$

FIG. 5. Radar images obtained along (a) the W3 traverse and (b) the W2 traverse. Interpreted sediment type also shown. Note the absence of the peat-lake sediment interface at the W2 traverse. 
conductivity and chargeability inversions. The result indicates that the IP response is due to an increase in polarization within the peat, rather than the effect of a change in bulk conduction. Polarization of the peat presumably results from the high surface charge density on the organic material. The zone of increased chargeability below $35 \mathrm{~m}$ observed between 170 and $250 \mathrm{~m}$ (Figure $7 \mathrm{~b}$ ) is resolved as zone of increased polarization, supporting a possible lithologic change at depth.

\section{TERRAIN CONDUCTIVITY MEASUREMENTS}

EM31 measurements along line 0 and the W6 traverse are plotted above conductivity images in Figures 6 and 7, respectively. Terrain conductivity values are consistent with estimated conductivity of the peat from the dc conductivity inversion. The EM31 profiles correlate with the thickness of the second layer in the dc conductivity inversion: where layer thickness increases, terrain conductivity increases. As discussed above, the conductive unit in the imaging represents the glaciomarine sediment, the lake sediment, and possibly the bottom portion of the peat. The EM31 response is likely mainly a response to glaciomarine sediment thickness. In the W6 traverse, the lake sediment thins towards well 5 and pinches out at $130 \mathrm{~m}$. The terrain conductivity variation between 0 and $130 \mathrm{~m}$ on the W6 traverse, hence, reflects glaciomarine sediment thickness. However, the lake sediment thickens from $150 \mathrm{~m}$ and the conductivity inversion indicates that the lake sediment is conductive. Therefore, the EM31 response in this section probably also partly reflects lake sediment thickness. Horizontal dipole measurements (not plotted) mimic vertical dipole measurements, although horizontal data are noisier. Given the reduced investigation depth in horizontal-dipole mode, this supports our belief that lake sediment thickness also influences the EM31 response.

Along line 0 and the W6 traverse, the EM31 conductivity is an indictor of glaciomarine sediment thickness. This premise holds if terrain conductivity responds to lake sediment thickness also, because GPR and electrical imaging show that lake sediment thickens where the glaciomarine sediment is thickest. This is expected, assuming this area was a topographic depression over the past 10000 years, with the thickest deposits of glaciomarine and lacustrine sediment accumulating in the
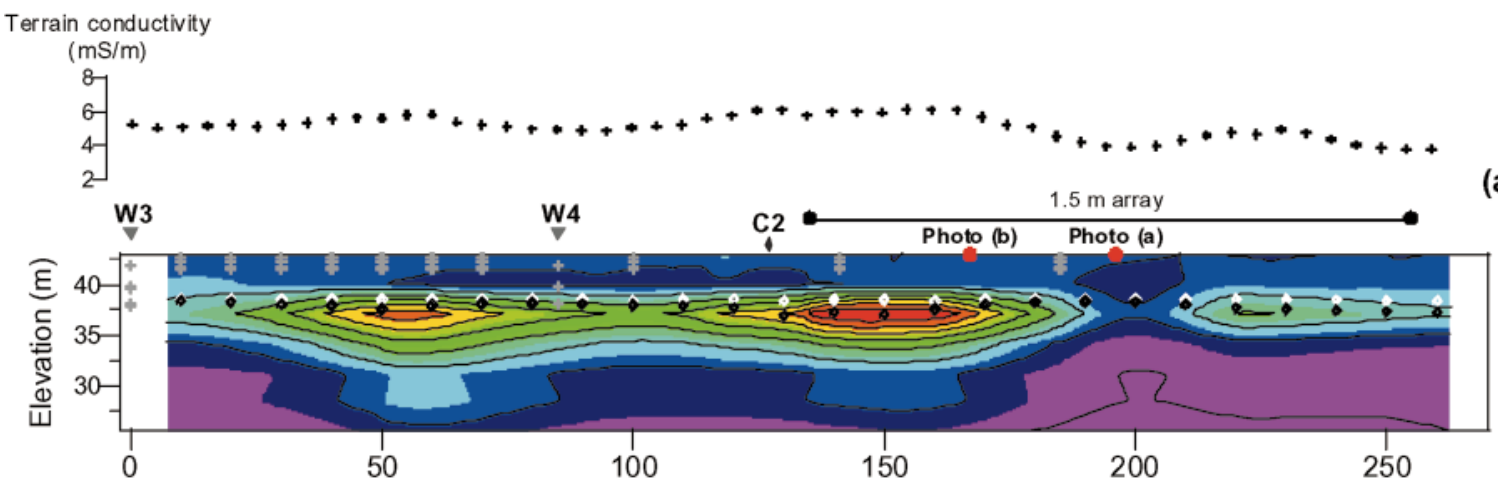

(a)

Distance from W3 $(\mathrm{m})$
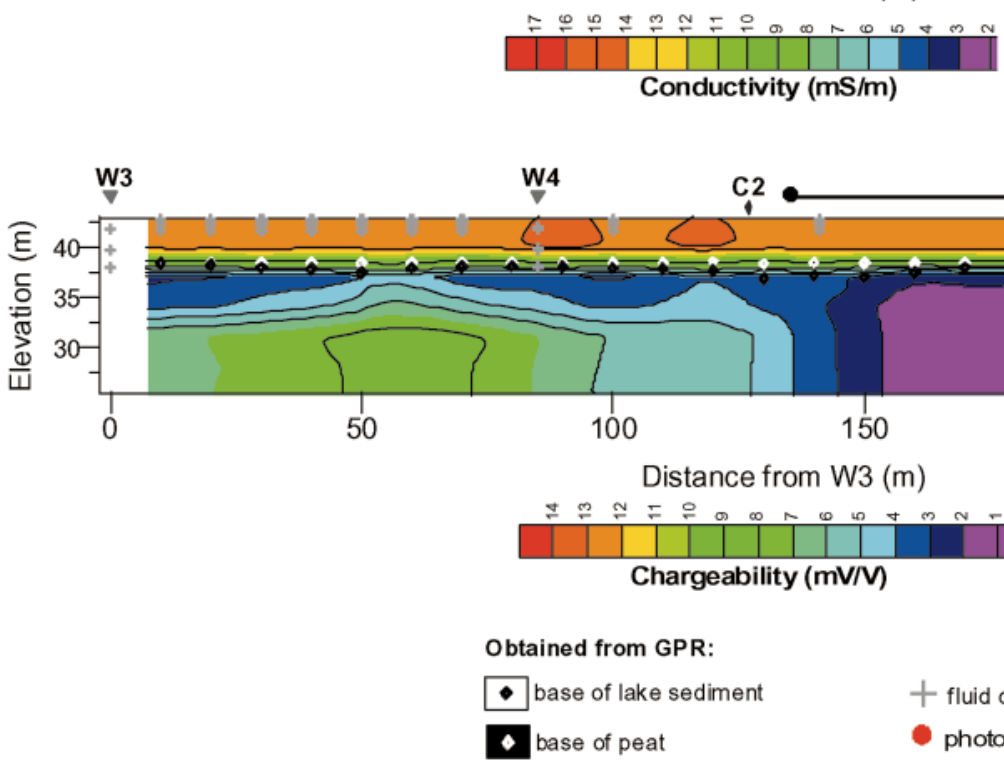

C2 $1.5 \mathrm{~m}$ array

$1.5 \mathrm{~m}$ array

(b)

FIG. 6. Electrical images along line 0 compared with prominent reflectors observed with GPR. Electrode $\mathrm{spacing}=5 \mathrm{~m}$, and maximum $\mathbf{n}=6$ : (a) conductivity, (b) chargeability. Terrain conductivity measurements, photograph locations, and fluid conductivity measurement locations also are shown. The high conductivity layer is interpreted as the glaciomarine silt-clay and lake sediment. See Figure 2 for line locations. Vertical scale exaggerated by factor of 2 . 
deepest parts of the basin. We made EM31 measurements on an irregular grid over approximately $18 \mathrm{~km}^{2}$. Measurement locations were restricted by dense vegetation in parts of the basin. Positions were determined using GPS with an accuracy of about $6 \mathrm{~m}$. Spot measurements on this irregular grid were integrated with data collected along traverses and interpolated using kriging. A contour plot of the EM31 data is shown in Figure 10. The point where peat is thickest on each GPR traverse is plotted for comparison. As discussed above, we expect some correlation between peat thickness, glaciomarine sediment thickness, and terrain conductivity. On the S2S3 and W3 traverses, the highest terrain conductivity occurs near the point of maximum peat thickness. The terrain conductivity along the W3 traverse is greater than that measured on the W6 traverse, despite the presence of a thicker layer of organic-rich sediment along the W6 traverse. The north-east to south-west trending lobe of high terrain conductivity intersecting the W3 and S2S3 traverses results from well-developed glaciomarine sediment

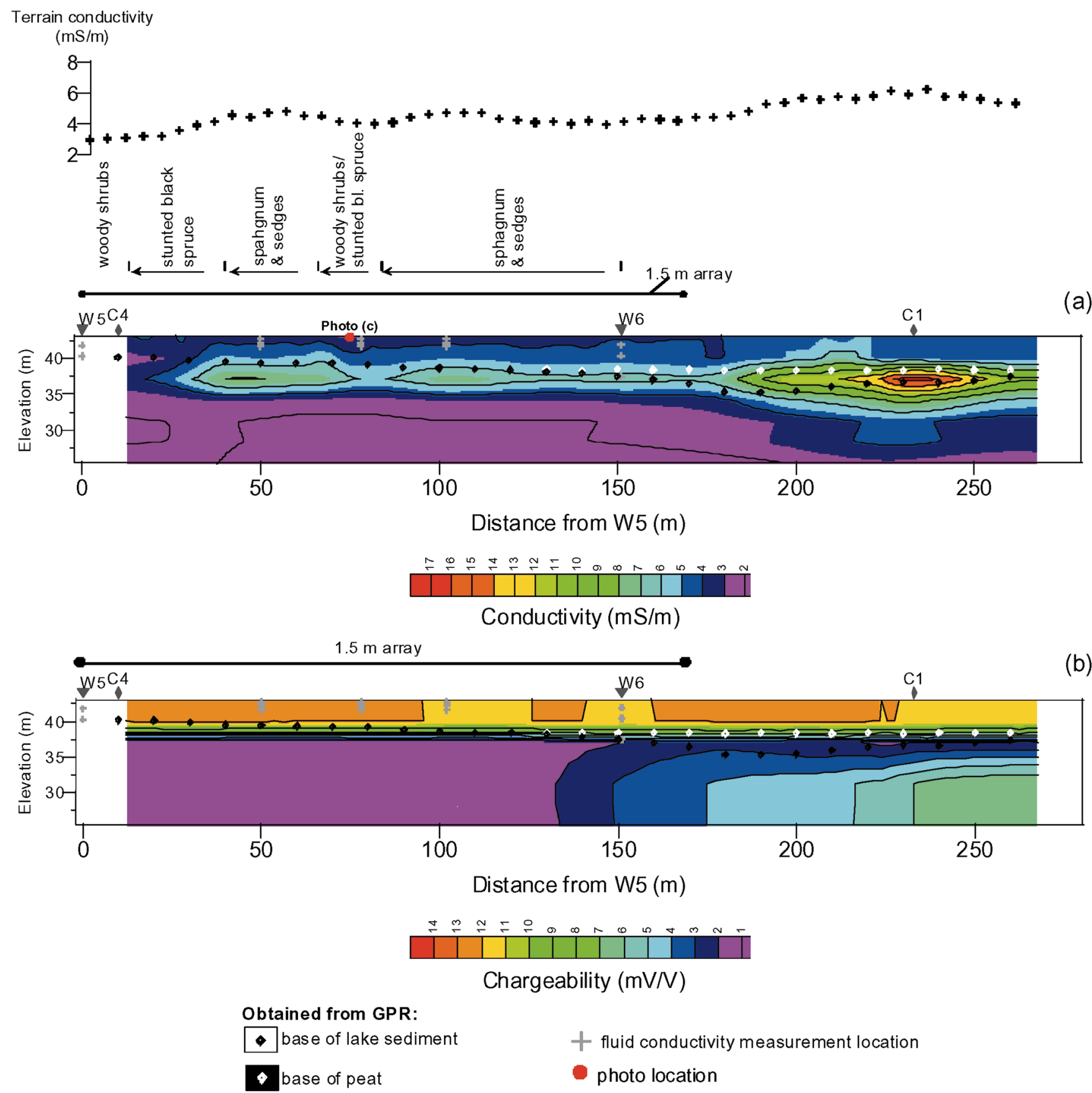

FIG. 7. Electrical images along the W6 traverse compared with prominent reflectors observed with GPR. Electrode spacing $=5 \mathrm{~m}$, and maximum $n=6$ : (a) conductivity, (b) chargeability. Terrain conductivity measurements, photograph locations, and fluid conductivity measurement locations also are shown. The high conductivity layer is interpreted as the glaciomarine silt-clay and lake sediment. See Figure 2 for line locations. Vertical scale exaggerated by factor of 2 . 
in this region, as verified from the 2-D electrical conductivity imaging along the S2S3 traverse (Figure 11). Hence, the contour plot of terrain conductivity appears to reflect variation in glaciomarine sediment thickness across the study area.

\section{HYDROGEOLOGY AND VEGETATION}

A distinct pattern of vegetation occurs within this peat basin, which is similar to that observed in other peatlands. Along line 0 and the W6 traverse, we observed sphagnum-and-sedgedominated areas where the glaciomarine sediment, determined from electrical imaging, was thickest. In regions where the glaciomarine sediment thins, the vegetation abruptly changes to woody shrubs and stunted black spruce (Figure 12). Where the glaciomarine sediment thins, the ground was notably drier, suggesting increased drainage in these areas (Figure 12). Alternatively, the root mat produced by the black spruce and woody shrubs may have increased the stability of the peat surface, preventing the compression of the peat and reducing ponding of water around our feet as we walked across the peatland. Hydrogeologic measurements indicate that in the summer, the water table is highest and downward vertical hydraulic gradients are present near wells $\mathrm{W} 3$ and $\mathrm{W} 4$, supporting our interpretation that the glaciomarine sediment is preventing drainage from the peat.

\section{DISCUSSION}

Integrated use of radar, resistivity, IP, and terrain conductivity was an effective approach to investigating the stratigraphy and hydrogeologic framework of a large peatland. Previous geophysical work in peat has concentrated on the application of GPR for resolving peat structure and the location of the mineral soil. In this study, GPR resolved the mineral soil contact to a maximum depth of $8 \mathrm{~m}$. The relatively high penetration depth resulted from the low conductivity of the
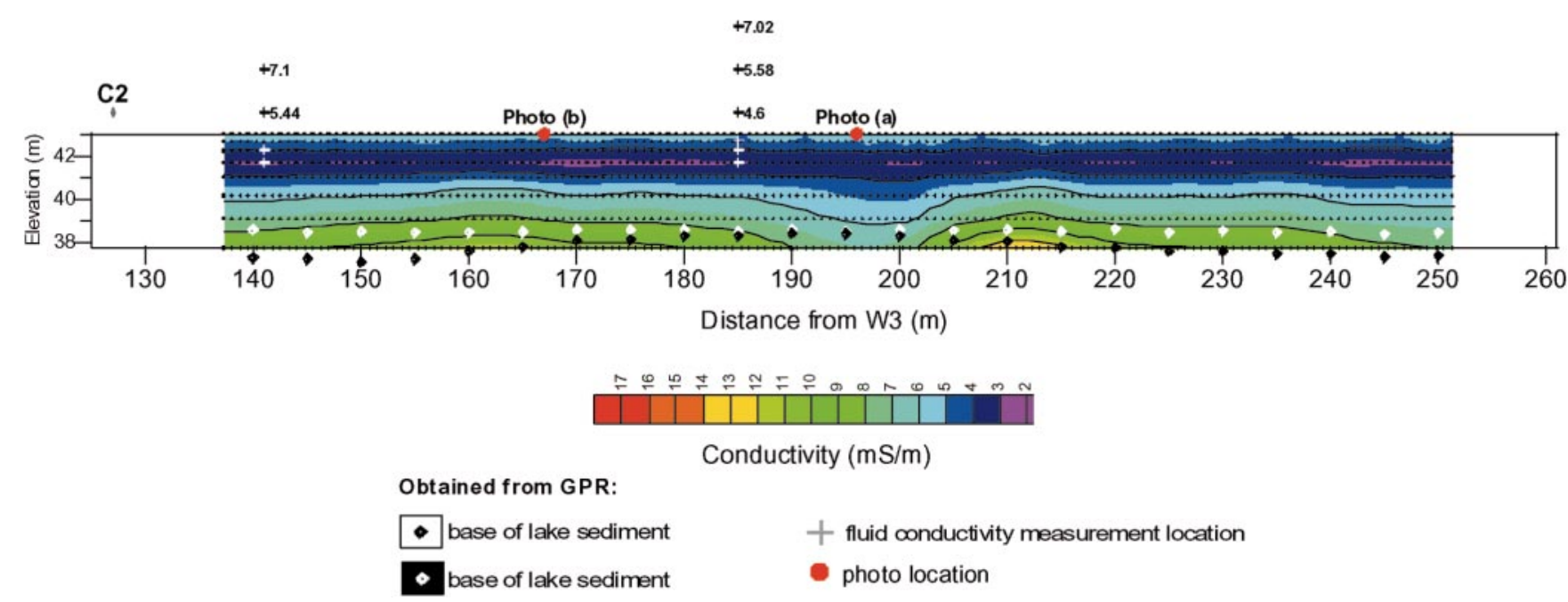

FIG. 8. Conductivity image along line 0 compared with prominent reflectors observed with GPR. Electrode $\mathrm{spacing}=1.5 \mathrm{~m}$, and maximum $n=6$. Photograph locations and fluid conductivity values $(\mathrm{mS} / \mathrm{cm})$ are also shown. The high conductivity layer is interpreted as the glaciomarine silt-clay and lake sediment. See Figure 2 for line location. Vertical scale exaggerated by factor of 2.
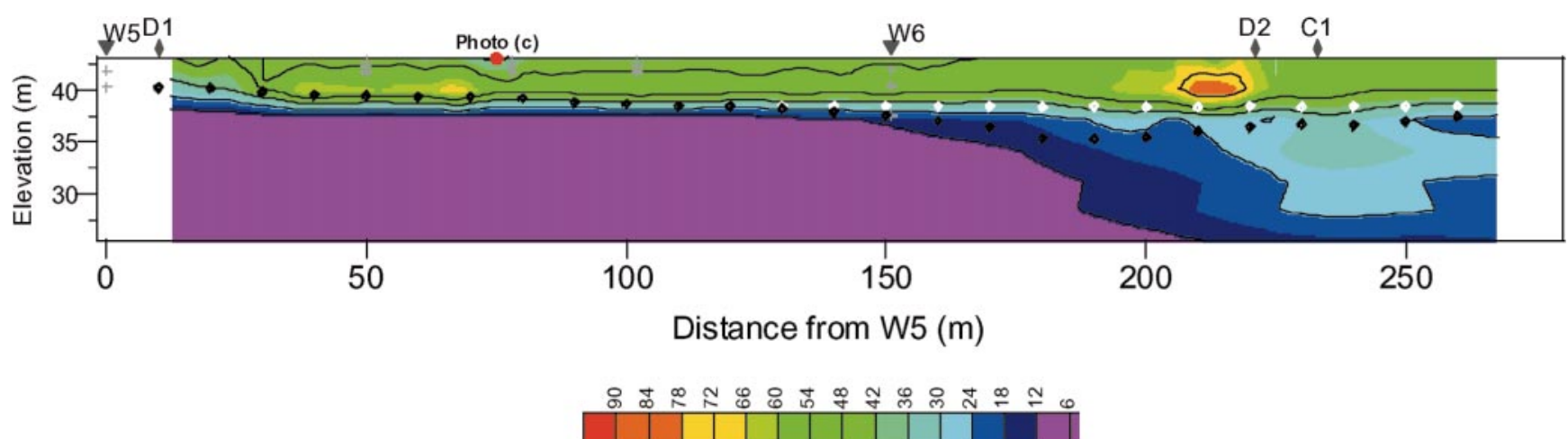

Normalized Chargeability $(\mu \mathrm{S} / \mathrm{m})$

Obtained from GPR:

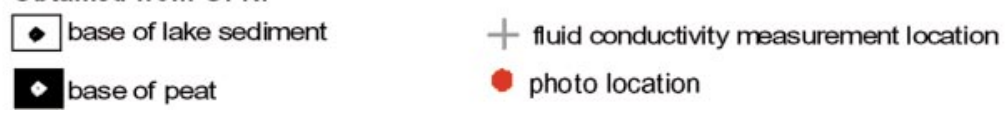

FIG. 9. Normalized chargeability image along the W6 traverse compared with prominent reflectors observed with GPR. Electrode spacing $=5 \mathrm{~m}$. See Figure 2 for line location. Vertical scale exaggerated by factor of 2 . 
peat soil. We also observe an important transition between peat and lake sediment. The GPR data reveal the sedimentary history of the basin: deposition of lake sediment on an irregular glacial surface, followed by development of a thick peat sequence.

Electrical imaging is valuable for investigating basin stratigraphy, including beneath the mineral soil contact. When the mineral soil is clay rich, as in this study, GPR investigation depth is limited to the mineral soil contact. The elevated conductivity of the confining clay, lake sediment, and lowermost portion of the peat complicated interpretation of 2-D conductivity images. These are resolved as a single layer in the image. Consequently, conductivity is not a good indicator of the base of the peat, but is a good indicator of the combined thickness of lake and glaciomarine sediment. Conductivity images obtained using a small electrode spacing suggest a gradual conductivity increase with depth in the peat, which possibly relates to a change in peat matrix conduction because fluid conductivity changes do not mimic the increase in bulk conduction.

In contrast to conductivity, chargeability is an excellent indicator of the thickness of the peat. Relative to the marine clay and lake sediment, the peat is chargeable. We associate this with the high surface charge and resulting high CEC of partially decomposed organic matter (Hobbs, 1986). Comparison with
GPR data shows that the base of the upper chargeable layer is coincident with the base of the peat. Computation of normalized chargeability indicates that the peat is more polarizable than the underlying clay and lake sediment. The chargeability of the peat is not just a result of changes in the bulk conduction. High fluid conductivity within peat can limit the value of the GPR method for determining depth to mineral basement (Theimer et al., 1994). This is not a limitation of the IP method. However, as stated, in our study, the interface determined from the IP inversion is the peat-lake sediment contact. Further IP measurements in peatlands will better resolve the value of the method.

Terrain conductivity mapping was an efficient and effective method for qualitatively defining variation in the thickness of the glaciomarine sediment across a large area of the peatland. Although measured changes in terrain conductivity were small, they were well above the noise level. Peatlands are often excellent environments for geophysical techniques because they are usually undeveloped land. An important factor in the correlation of terrain conductivity with glaciomarine sediment thickness is the uniformity in the electrical properties of the peat. Conductivity and IP inversions indicate a laterally uniform upper layer, although conductivity may increase with depth. Direct measurements of fluid conductivity show

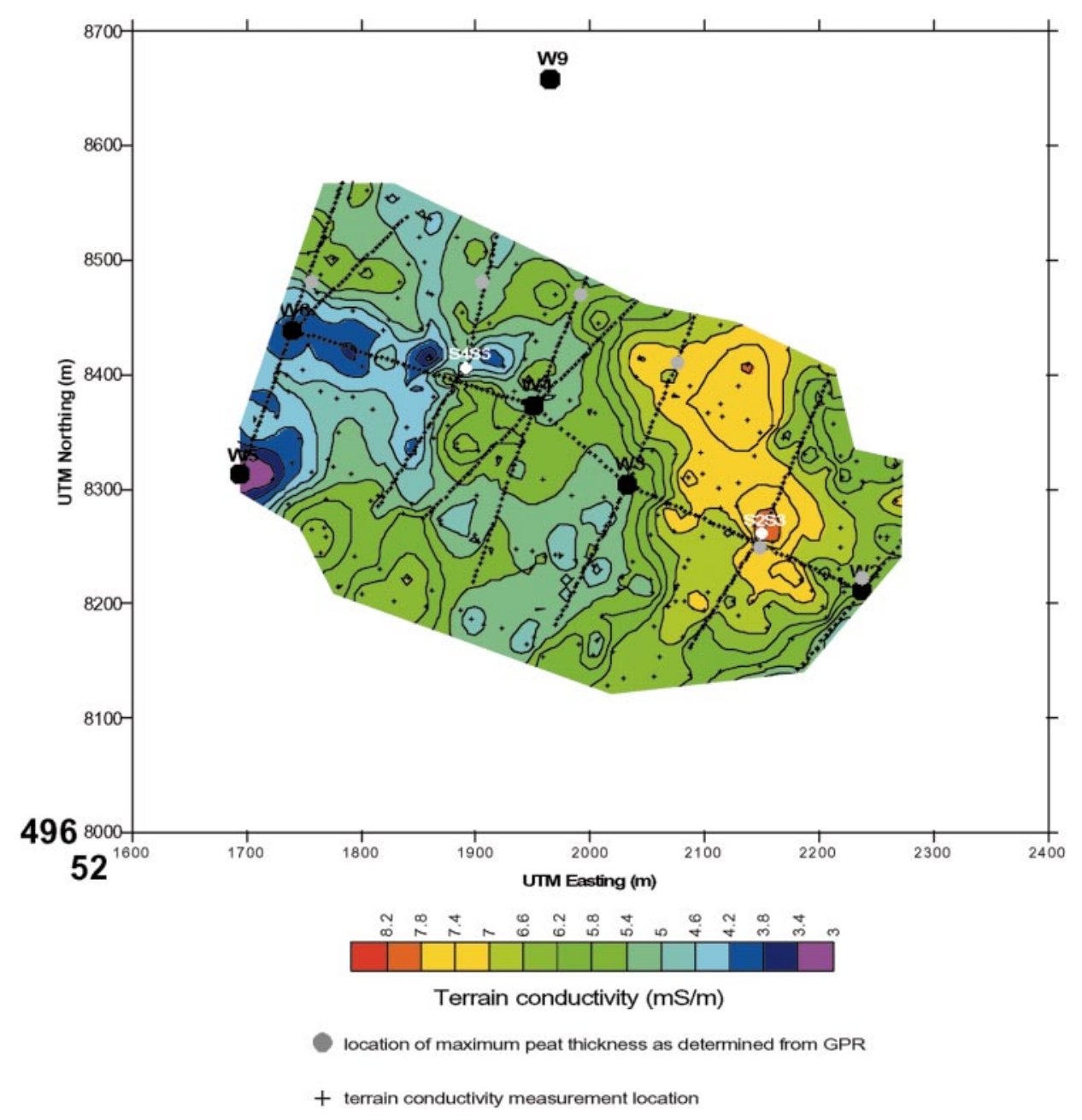

FIG. 10. Interpolated terrain conductivity map for the surveyed area of the peat basin. 
minimal variability laterally. Given the lateral uniformity of the peat, terrain conductivity is primarily sensitive to the development of the glaciomarine sediment. In a peatland with greater lateral variability in fluid chemistry, terrain conductivity measurements will not be as sensitive to mineral soil properties.

We also observe a direct correlation between geophysical data and patterns of vegetation and hydraulic gradients. The geophysical interpretation offers an explanation for the distribution of vegetation within the peatland. The controls on vegetation distribution within such peatlands are not fully understood. It is generally assumed that availability of nutrients is the primary factor determining vegetation type. Our geophysical data set supports the premise that, in this peatland, stratigraphy and hydrogeology are important controls on vegetation type. We hypothesize that vertical flow, controlled by the thickness of the confining glaciomarine silt-clay layer, controls the nutrient availability by regulating solute transport and the position of the water table in the peat. Evapotranspiration may be important in driving upward vertical flow in the upper meter of peat because we observed diurnal fluctuations in the water table of $0.5 \mathrm{~cm}$ during summer months. Where the confining glaciomarine sediment is thickest, groundwater flow is impeded, allowing the maintenance of a higher water table. This high hydraulic head associated with the elevated water table drives flow downward through the peat, flushing solutes from the peat. This model is similar to that proposed by Siegel (1983), but our data suggests a mechanism for groundwater mounding within Caribou Bog. Lapen et al. (1996) also identified a correlation between peatland vegetation, hydraulic gradients, and GPR-derived subsurface features along a shallow wetland catena in Newfoundland. They attributed bog communities to the presence of placic horizons (unsaturated mineral soil/saturated mineral soil contacts) within the mineral soil underlying the bog, restricting vertical drainage and maintaining wet surface conditions.

Our data indicates that IP, EM, and resistivity measurements complement GPR measurements in peatlands. We are unaware of any previous published studies that combine these methods for studying peatlands. Furthermore, we believe that further refinement of these methods could lead to a better understanding of the hydrogeologic processes within peatlands. Recent developments in hardware and software allow rapid collection and interpretation of large data sets, allowing the imaging of temporal changes due to dynamic hydrologic processes. We suggest that geophysical methods can augment the delineation of wetlands and the interpretation of wetland processes.

This field study highlights the need for laboratory studies of the electrical properties of peat. Only the dielectric properties of peat are understood. As noted by Theimer et al. (1994), the relationship between bulk conductivity, fluid conductivity and structural properties of peat is unclear. Archie's Law (1942) assumes a nonconducting matrix and was derived for sedimentary rocks, although it also holds for unconsolidated mineral soils saturated with a fluid of sufficiently high salinity. It is unclear whether organic sediments conform to this rule. Our study also identifies the need for laboratory IP measurements to identify the surface chemistry controlling the IP response of peat. Such studies will enhance the field application of electrical geophysical methods in the study of peatlands.

\section{CONCLUSIONS}

This integrated electrical study of a large peatland in Maine demonstrates the value of GPR, resistivity imaging, IP imaging,

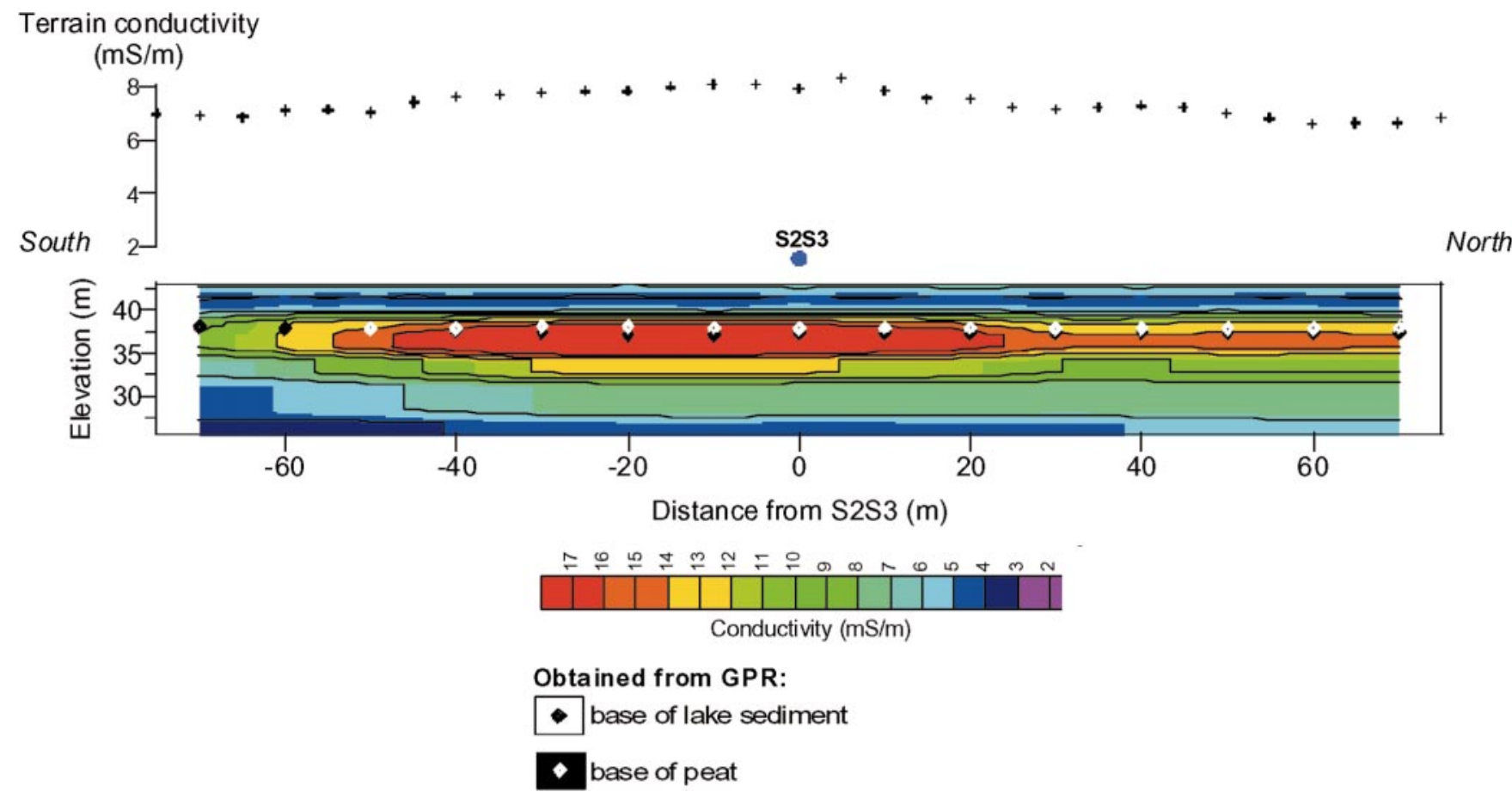

FIG. 11. Conductivity image along the S2S3 traverse compared with prominent reflectors observed with GPR. Electrode spacing $=5 \mathrm{~m}$. The high conductivity layer is interpreted as the glaciomarine silt-clay and lake sediment. See Figure 2 for line location. 
and EM terrain conductivity mapping to studies of peatlands. Geophysical data were compared with direct sampling of peat thickness, peat composition, fluid chemistry, and vegetation patterns. The mineral soil contact was resolved up to $8 \mathrm{~m}$ depth. An important boundary between peat and lake sediment was also mapped with GPR. No information was obtained beneath the mineral soil contact from GPR.

Conductivity and IP imaging are excellent methods for investigating electrical properties of the peat and the mineral soil.
Imaging to a depth of $18 \mathrm{~m}$ identified the peat, the confining clay unit, and an unidentified resistive unit beneath the clay. The conductivity images resolved the variability in thickness of the confining glaciomarine sediment, an important parameter controlling the hydrogeology of this peatland. However, the conductivity image did not accurately define the base of the peatland, due to an observed gradual increase in conductivity with depth within peat and lake sediment. IP imaging, hitherto unreported in peatland studies, was an excellent indicator of

(a)

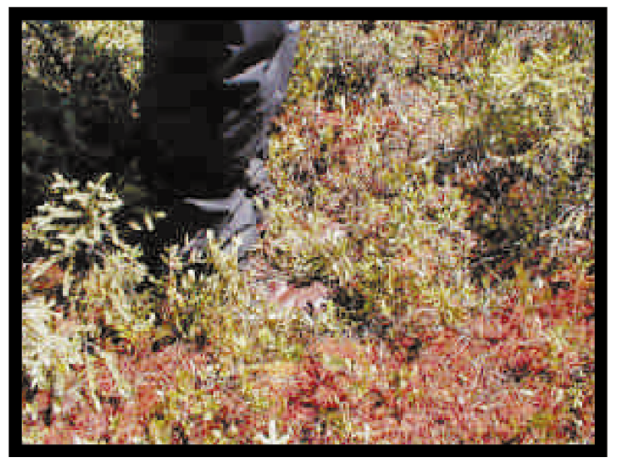

(b)
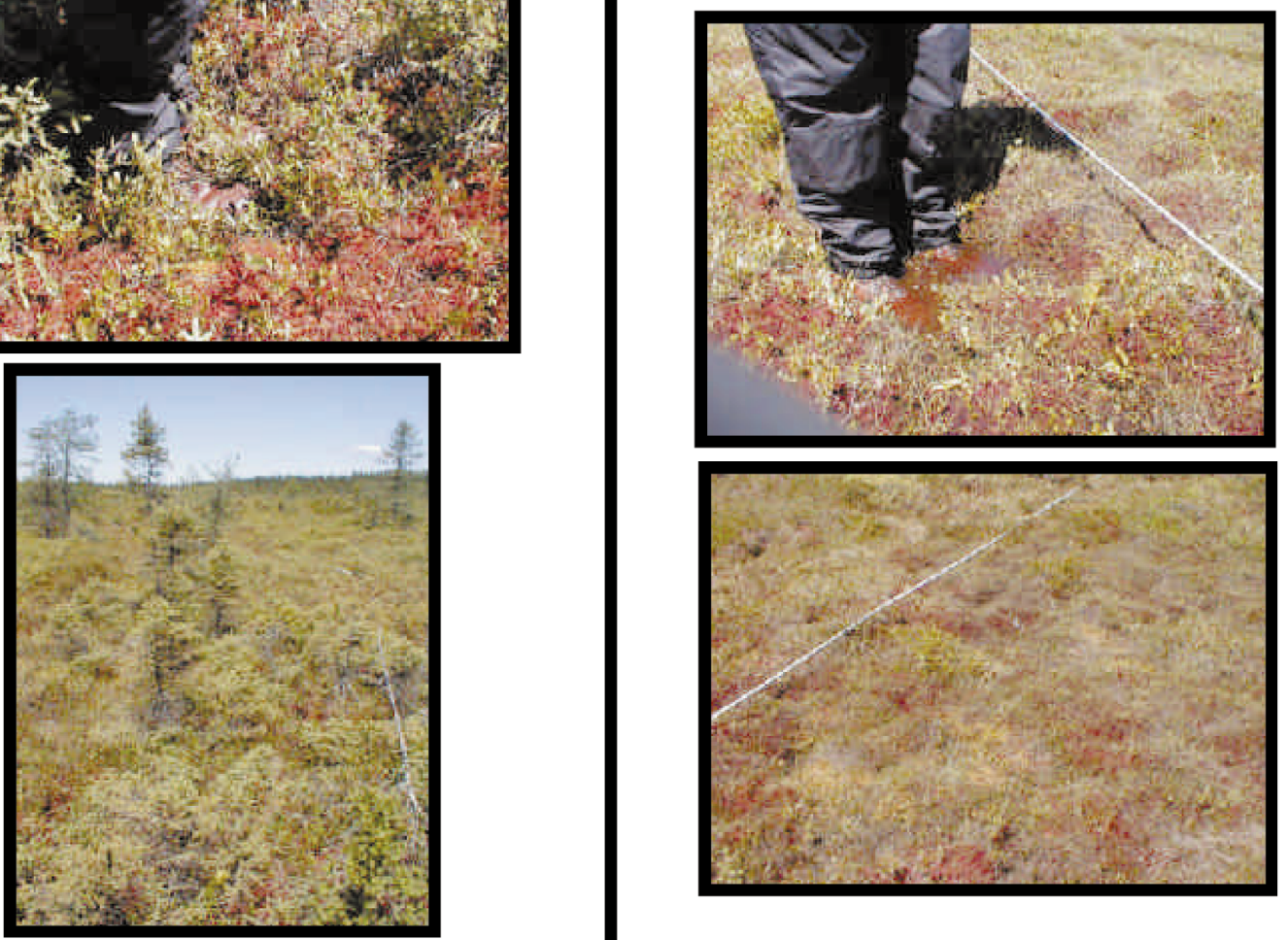

(c)

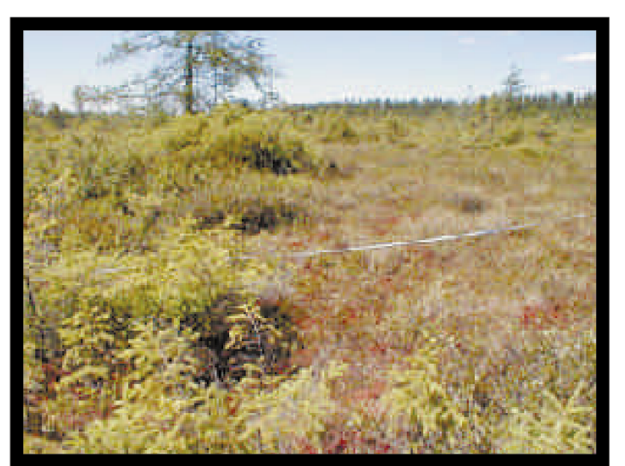

FIG. 12. Photographs of vegetation observed at (a) $190 \mathrm{~m}$ on line 0 , (b) $165 \mathrm{~m}$ on line 0 , and (c) $75 \mathrm{~m}$ on the W6 traverse. In (a) and (b), a close-up of the vegetation (boot shown to emphasize different saturation) is included. In (a), the glaciomarine sediment and lake sediment layers are thin, and vegetation is woody shrubs and stunted black spruce, indicative of drainage. In (b) the glaciomarine sediment and lake sediment layers are thick, and sphagnum and sedges are the dominant vegetation. In (c), the vegetation abruptly changes from sphagnum lawn with sedges to woody shrubs and stunted black spruce towards well 5 , consistent with abrupt thinning of the glaciomarine sediment as resolved from electrical imaging. 
the thickness of peat. Peat is chargeable, due to enhanced polarization presumably caused by the high surface charge density on the organic matrix. Terrain conductivity measurements correlated with thickness of the confining glaciomarine sediment, as inferred from the conductivity imaging. Terrain conductivity measurements provided a qualitative assessment of the variation in development of the confining glaciomarine sediment over $17.6 \mathrm{~km}^{2}$.

This integrated geophysical approach provides valuable insight into important controls on peatland hydrology and its impact on the distribution of vegetation communities in a peatland. We observed a correlation between the thickness of a glaciomarine confining unit and vegetation, reflecting the linkage between hydrogeology and plant communities (Siegel, 1983; Siegel and Glaser, 1987) and the impact of confining layers on groundwater flow within the peatland. Where the glaciomarine sediment thins, sphagnum and sedges give way to areas dominated by stunted evergreens and woody shrubs. The collection and interpretation of geophysical data improved the stratigraphic and hydrogeologic understanding of Caribou Bog. Controlled laboratory experiments, investigating the relationship between physical and electrical properties of peat, will further enhance the value of electrical methods in such studies.

\section{ACKNOWLEDGMENTS}

This work was supported in part by the National Science Foundation under EAR-0105322. Lee Slater also acknowledges support from the University of Missouri Research Board and a University of Missouri Faculty Research Grant. He is grateful for this support. Graduate students Danney Glaser and Robin Evensen provided invaluable field support, for which we extend our thanks. We also thank Maine Agricultural and Forestry Experiment Station for supporting this work. The constructive review comments of John Lane, William Sauck, Philip Carpenter, and Mark Vendl improved the quality of this manuscript.

\section{REFERENCES}

Archie, G. E., 1942, The electrical resistivity log as an aid in determining some reservoir characteristics: Trans. Am. Inst. Min. Metall. Pet. Eng., 146, 54-62.

Ayotte, J. D., Mack, T. J., and Johnston, C. M., 1999, Geophysical surveys of Country Pond and adjacent wetland, and implications for contaminant-plume monitoring, Kingston, New Hampshire, 1998: U. S. Geol. Surv. Open-File Report 99-51.

Beres, M., and Haeni, F. P., 1991, Application of ground-penetrating radar methods to hydrogeologic studies: Ground Water, 29, 375-386.

Bridgham, S., Pastor, J., Janssens, J., Chapin, C., and Malterer, T., 1996, Multiple limiting gradients in peatlands: A call for a new paradigm: Wetlands, 16, 45-65.

Daily, W., and Ramirez, A, 1995, Electrical resistance tomography during in-situ trichloroethylene remediation at the Savannah river site: J. Appl. Geophys. 33, 239-249.

Gajewski, K., 1987, Environmental history of Caribou Bog, Penobscot Co., Maine: Naturaliste Canadien, 114, 133-140.

Glaser, P., 1987, The development of streamlined bog islands in the continental interior of North America: Arctic and Alpine, 19, 402-413.

Glaser, P., Wheeler, G., Gorham, E., and Wright, H., 1981, The patterned mires of the Red Lake Peatlands, northern Minnesota: Vegetation, water chemistry, and landforms: J. Ecology, 69, 575-599.

Glaser, P., Siegel, D., Romanowicz, E., and Shen, Y., 1997, Regional linkages between raised bogs and the climate, groundwater, and landscape of north-western Minnesota: J. Ecology, 85, 3-16.

Glooschenko, W., Roulet, N., Barrie, L., Schiff, H., and McAdie, H., 1994, The northern wetland study (NOWES): An overview: J. Geophys. Res., 99, 1423-1428.

Gorham, E., 1991, Northern peatlands: Role in the carbon cycle and probable responses to climatic warming: Ecological Applications, 1, 182-195.

Gorham, E., Eisenreich, S., Ford, J., and Santelmann, M., 1985, The chemistry of bog waters, in Stumm, W., Ed., Chemical processes in lakes, 339-363.

Hanninen, P., 1992, Application of ground penetrating radar techniques to peatland investigations, in Hanninen, P., and Autio, S. Eds., Geological Survey of Finland Special Paper 16, 217-221.

Hanninen, P., and Hanninen, P., 1991, Water content of peat measured with the aid of its dielectric properties, in Autio, S., Ed., Geological Survey of Finland Special Paper 12, 159-162.

Hobbs, N., 1986, Mire morphology and the properties and behaviour of some British and foreign peats: Quart. J. Engin. Geol., 19, 7-80. Jol, H. M., and Smith, D. G., 1995, Ground penetrating radar surveys of peatlands for oilfield pipelines in Canada: J. Appl. Geophys., 34, 109-123.

Lapen, D. R., Moorman, B. J., and Price, J. S., 1996, Using groundpenetrating-radar to delineate subsurface features along a wetland catena: Soil Sci. Soc. Am. J., 60, 923-931.

Lowe, D. J., 1985, Application of impulse radar to continuous profiling of tephra bearing lake sediments and peats: An initial evaluation, New Zealand J. Geol. Geophys., 28, 667-674.

MacInnes, S., and Zonge, K., 1996, Two dimensional inversion of resistivity and IP data with topography: Presented at 102nd Ann. NorthWest Mining Assoc. Convention.

Malmer, N., 1986, Vegetation gradients in relation to environmental conditions in northwestern European mires: Can. J. Botony, 64, 375-383.

McNamera, J., Siegel, D., Glaser, P., and Beck, R., 1992, Hydrogeologic controls on peatland development in the Malloryville Wetland New York: J. Hydrology, 140, 279-296.

Meyer, J. H., 1989, Investigation of Holocene organic sediments-A geophysical approach: Internat. Peat J., 3, 45-57.

Mitsch, W., and Gosselink, J. 1993, Wetlands: Van Nostrand Reinhold.

Nobes, D. C. Theimer, B. D., and Warner, B. G., 1989, Grant 310: Subsurface radar profiling of two peatlands in southern Ontario, in Milne, V. G., Ed., Geoscience Research Grant Program: Summary of research 1987-1988: Ontario Geol. Surv., 53-58.

Pelletier, R. E., Davis, J. L., and Rossiter, J. R., 1991, Peat analyses in the Hudson Bay Lowlands using ground penetrating radar, in Putkonen, J., Ed., IGARSS'91; Remote sensing; global monitoring for earth management: Inst. Electr. Electron. Eng., 2141-2144.

Poole, G. C., Naiman, R. J., Pastor, J., and Stanford, J. A., 1997, Uses and limitations of ground penetrating radar in two riparian systems, in Gibert, J., Mathieu, J., and Fournier, F., Eds., Groundwater/surface water ecotones: Biological and hydrological interactions and management options: Cambridge Univ. Press, 140-148.

Reeve, A., Siegel, D., and Glaser, P., 2000, Simulating vertical flow in large peatlands: J. Hydrology, 227, 207-217.

Reynolds, J., 1997, An introduction to applied and environmental geophysics: John Wiley.

Shotyk, W., 1988, Review of the inorganic geochemistry of peat and peatland waters: Earth-Science Reviews, 25, 95-176.

Siegel, D., 1983, Ground water and the evolution of patterned mires, glacial lake Agassiz peatlands, Minnesota: J. Ecology, 71, 913-921.

Siegel, D., and Glaser, P., 1987, Groundwater flow in a bog-fen complex, Lost River Peatland, northern Minnesota: J. Ecology, 75, 743-754.

Siegel, D. Reeve, A., Glaser, P., and Romanowicz, E.. 1995, Climatedriven flushing of pore water in peatlands: Nature, 374, 531-533.

Slater, L., and Lesmes, D., 2002, IP interpretation in environmental investigations: Geophysics, 67, 77-88.

Theimer, B. D., Nobes, D. C., and Warner, B. G., 1994, A study of the geoelectrical properties of peatlands and their influence on

ground-penetrating radar surveying: Geophys. Prosp., 42, 179-209.
Vanhala, H., 1997, Mapping oil-contaminated sand and till with the spectral induced polarization (SIP) method: Geophys. Prosp., 45, 303-326.

Vanhala, H., Soininen, H., and Kukkonen, I., 1992, Detecting organic chemical contaminants by spectral-induced polarization method in glacial till environment: Geophysics, 57, 1014-1017.

Vinegar, H. J., and Waxman, M. H., 1984, Induced polarization of shaly sands: Geophysics, 49, 1267-1287.

Waddington, J. M., and Roulet, N. T., 1997, Groundwater flow and dissolved carbon movement in a boreal peatland: J. Hydrology, 191, 122-138.

Warner, B. G., Nobes, D. C., and Theimer, B. D., 1990, An application of ground penetrating radar to peat stratigraphy of Ellice Swamp, southwestern Ontario: Can. J. Earth Sci., 27, 932-928.

Wende, S., and Kirsch R., 1993, Geophysical mapping of organic sediments, in Negendank, B., and Zolitschka, B., Eds., Paleolimnology of European maar lakes: Springer-Verlag, Berlin. 